\title{
ECONOMIC EFFECTS OF THE PHILOSOPHICAL CONCEPT OF COMMUNITY*
}

\author{
ALFONSO DÍAZ VERA
}

Fecha de recepción: 30 de enero de 2020

Fecha de aceptación: 22 de junio de 2020

"Society is like the air, necessary to breathe but insufficient to live on."

George Santayana.

\section{I \\ INTRODUCTION}

Introductory textbooks in the History of Economic Thought in use at colleges and universities devote little space to Scholasticism and its influence. Even those that do not start straight with the Physiocrats, Thomas Aquinas appears stuck between Ancient Greek Philosophers and Thomas Mun. Scholasticism with "medieval" economic thought characterized as primitive and focused on "obsolete" issues like usury and just price. Sometimes it is even categorized among the schools that promote State intervention'.

* This work was supported by the European Regional Development Fund (ERDF)/ Spanish Ministry of Science, Innovation and Universities/State Agency of Research(AEI)/ National Programme for Fostering Excellence in Scientific and Technical Research/"Projections of Spanish Scholasticism on British and Anglo-Saxon Thought" (reference number: FFI2017-84435-P).

1 "Aquinas as the Scholastics were overwhelmingly concerned with questions of the organization and control of economic life - in regard to which they adopted laws and principles which severely restricted entrepreneurial activity" (Medema \& Warren eds., 2013, p.19). 
This was not the opinion of F.A. Hayek, who appreciated some Scholastic authors as part of the individualistic tradition of Western civilization rooted on the legacy of Ancient Greeks and Romans like Pericles, Thucydides, Cicero and Tacitus².

In his famous Road to Serfdom (1944) F.A. Hayek assumed that Western Civilization had abandoned the right road and the individualistic tradition by the last quarter of the XIX Century. The abandoned road that Hayek refers to is that grounded on Greek, Roman and Medieval tradition and later paved by the ideas of authors like Cobden, Bright, De Tocqueville, Lord Acton, Adam Smith, Hume, Locke or Milton ${ }^{3}$.

Hilaire Belloc ${ }^{4}$ located the abandonment of the liberal tradition around the same historical time. He would have agreed with most of the names in Hayek's list, especially Cobden and Bright, but would have added those of radicals like Fox and Cobbett. Regarding more far away sources of Western thought, he would have included Aristotle, Aquinas and the Spanish Jesuit Francisco Suárez.

Some of the authors mentioned above represent different traditions in the political philosophy. These traditions could be referred as the "old" and the "new", following Leo Strauss in the idea of Machiavelli as the turning point. This essay approaches the influence of the political philosophy in the changes referred by Hayek and Belloc by examining the differences between the old and the new concept of community.

Both Hayek and Belloc saw the abandonment of the right road in the neglection of the traditional liberal principles and civil ideal. This ideal, wrote Belloc, was abandoned and replaced by the needs of practical policies. The civil ideal, in Belloc's opinion, takes shape in an individual who has the qualities of self-control, thrift and personal honor. This tendency "involves an attack upon personal production, personal accumulation, and consequent personal

2 Despite he thought that the influence of Aristotle's systematization of morals, spread and amplified by Aquinas, was behind the social theory that grounded socialist thought (Hayek, 1992, p.47).

3 Hayek (2006), p. 13.

${ }^{4}$ Hilaire Belloc (1870-1953) was an English writer, journalist and historian. 
possession: a theory which makes the individual and all the individual virtues of small account, and desires to emphasize rather the vague qualities of the State"5. Belloc's ideal was a society of individuals with the kind of personal integrity that holds a contract sacred, in contrast to the idea of the State as the authority to enforce the completion of contracts, releasing men from private rectitude, replacing it instead by State control ${ }^{6}$. The change of trend against "individual virtues" and in favor of, in Belloc's language, "the vague qualities of the State" is rooted on anthropological and philosophical considerations. Some of the above are of a metaphysical nature.

Professor Jesús Huerta de Soto claimed in a recent conference the importance of theological concepts and ideas in economic analysis7. In our case, a fundamental theological concept to contextualize would be the claim that state intervention is original sin. This idea is related to the "state of nature" or the hypothesis behind the anthropological basis of the community.

This paper will try to analyze the main Scholastic ideas about the nature of community and government compared with the changes introduced by later authors, and to trace the possible influence of these changes on the economic role of the State in modern societies. On this basis, we will try to discuss about the importance of Scholastic thought and Theological ideals like original sin to economic mentality, specially about the demand for State intervention.

II

TRADITIONAL POLITICAL THEORY: SUAREZIAN CONCEPT OF COMMUNITY AND ITS INSTITUTIONS.

Francisco Suáre ${ }^{8}$ could be considered the most modern representative of the old tradition. He follows and summarizes the classical

\footnotetext{
${ }^{5}$ Ibid, p. 4.

6 Belloc (1897), p. 4-5.

7 Huerta de Soto (2017).

${ }^{8}$ Francisco Suárez (1548-1617), Spanish Jesuit priest, philosopher and theologian.
} 
tradition in Political Philosophy that, since Aristotle, emphasizes the moral nature of the link between the members of a community. At the same time, we could consider him modern because, in Belloc's words, "he it was who, completing the work of his contemporary and fellow Jesuit, Bellarmine, restated in the most lucid and conclusive fashion the fundamental doctrine that Governments derive their authority, under God, from the community"9.

Suárez's vision regarding political issues gives priority to moral issues. Thus, like Aristotle, he considers that the bond that binds citizens together is of a moral nature ${ }^{10}$. This way Suárez makes explicit what he considered to be the error of Machiavelli, followed by the politicians of his time, where the emergency of practical questions ${ }^{11}$ suggests that "true and stable king cannot be the one who follows the laws of virtue and submits to them in everything"12.

Unlike Machiavelli, Suárez inherits the classical, Patristic and Scholastic views in his works about Political Philosophy and Law ${ }^{13}$. Regarding his concept of community, he distinguished two different types: the "imperfect communities" (in the sense that they do not include everybody), like municipalities or families, and the "perfect communities", that have their origins in the free will of families and municipalities to get together in a political body. According to Suárez, families, as imperfect communities, have the economic (in the sense of management of the oikos ${ }^{14}$ ) power, while the political power is left to the political body of the "perfect community" that families freely constitute. The origin of the political body is free will and consent, but the rules that apply to this political body do not come from the same source. The political body has

9 Belloc (1954), p. 233.

10 Suárez, De Legibus, Book I, Chapter 6, 19; in López Atanes, Bustos \& Villena eds. (2010), p. 50.

11 "(...) based only on that otherwise the temporary state cannot be preserved." (Suárez, De Legibus, Book III, Chapter. 12, 2; in López Atanes, Bustos \& Villena eds., 2010, p. 78).

12 Ibid., p.78.

13 Tractatus de legibus ac Deo legislatore (1612), Defensio fidei catholicae et apostolicae adversus Anglicanae sectae errores (1613), De opere sex dierum (unfinished at his dead in 1617).

${ }^{14}$ From Old Greek, house. This sense, literally "management of the house", is different from what we use to call "economics" nowadays. 
its natural rules as a thing, and these rules do not depend on the will of people (or on the will of the Government as head of the political body) ${ }^{15}$.

The idea of the political body as a thing freely established by human will, but with rules that do not depend on this will is key and confluent with the thought of another Spanish Jesuit priest, philosopher of and theologian: Luis de Molina. Molina was a contemporary and influential to Francisco Suárez, and was referred to by Hayek in his works ${ }^{16}$. Hayek pointed out that under these "Spanish Jesuits of the sixteenth century, naturalis became a technical term for such social phenomena as were not deliberately shaped by human will" and cites the example of "natural price" in Molina as a result "from the thing itself without regards to laws and decrees" 17 .

The Suarezian idea of the political body of the community as a thing (rather than a subject) with objective rules contrasts with the more modern vision based on social contractualism. In contrast to Suárez's political thinking, modern theories do not include a natural distribution of powers (political and economic) between Government and families, and so do not trace a limitation in governmental competencies, which are left to pacts between the members of the community. In the modern view, this "freedom of contract" for the community and its institutions of Government also apply to its nature and rules, unlike in Suárez's view. Economic power (in the sense of house management) could also be

15 Rothbard summarized this idea with the following words: "To Suarez the power of the ruler is in no sense a divinely created institution since political power by natural and divine law devolves solely on the people as a whole. The community as a whole confers political power on the king or other set of rulers; and while Suarez believed that natural law requires some form of state, the sovereign power of any particular state 'must necessarily be bestowed upon him by the consent of the community"' (Rothbard, 2006, p.160).

16 Marjorie Grice-Hutchinson (1908-2003), a Ph. D. student of Hayek, wrote under his supervision a thesis that was the base of his seminal work "The school of Salamanca; readings in Spanish monetary theory, 1544-1605", where the economic thought of Molina and other Spanish Late Scholastics is analyzed. The influence of the "School of Salamanca" in economics was also claimed by other economists like Joseph Schumpeter.

17 Hayek (2013), p. 21. 
delegated to the Government. This way, the new vision "subjectivizes" the political body and its head figure, the Government, of which it is no longer considered an object with rules inherent to the thing itself.

In contrast to the mechanicism of other authors who use the simile of the contract, the vision of the human community in Suárez is clearly organic ${ }^{18}$. In Suárez's view, the political community is not a mere pact for the exchange of freedom for security, as could be deduced from Hobbes's thesis. For Suárez, although the formation of the community is produced by will or consent, the power of the same does not derive from that consent, because "this power is not given totally or partially in each of them; (...) not even in the rough set or conglomerate of men"19. That power, which "does not appear in human nature until men come together in a perfect community and unite politically" ${ }^{20}$, would have, in Suárez's view, a divine origin and would be given as a property that is followed by the very nature of the community as a thing. It is important to note that in Suárez "divine origin" of the power does not implies "absolute power" for the ruler, but rather a limited one that derives from the natural and restricted role and characteristic role of community as a thing. The powers of the ruler, as representative of the community, cannot be extended arbitrarily, and so would end just when the also natural and exclusive competencies and functions of the family begin. This idea is nothing but a particular expression of the principle of subsidiarity, which still inspires the Social Teaching of the Catholic Church. This principle, in its restrictive sense, requires the State "to refrain from anything that would de facto restrict the existential space of the smaller essential cells of society"21.

18 Suárez uses frequently anatomic metaphors like "the political body, by the fact of producing itself in its own way, has the lordship and the government of itself and therefore also has power over its members and a peculiar lordship over them". (Suárez, De Legibus, Book III, Chapter 3, 6; in López Atanes, Bustos \& Villena eds.,2010, p. 76).

19 Suárez, De Legibus, Book III, Chapter 3, 1; in López Atanes, Bustos \& Villena eds.,2010, p. 75 .

${ }^{20}$ Ibid, p. 76.

${ }^{21}$ Compendium of the Social Doctrine of the Church, 187. 
III

\section{THE EMERGENCE OF MODERN POLITICAL PHILOSOPHY}

The realistic cynicism of Machiavelli, "father of modern political theory" 22 in the words of Leo Strauss, broke up with the traditional concepts of Political Philosophy one century before Suárez. Some decades after Machiavelli, who was also influential on Spinoza and Bacon, Hobbes wrote his famous Leviathan ${ }^{23}$, trying a scientific approach to Political Philosophy that neglects classical views about the matter. Hobbes, who wanted to break with the Aristotelian tradition and to approach Political Philosophy scientifically, uses abstraction to develop a contractual theory about the origin of the community. This abstraction was called "state of nature" or "natural condition of mankind", a theoretical world with no rules, civilization or government to limit human nature. In such "state of nature" life would be "nasty, brutish and short." 24 Locke, and later Rousseau, developed their theories from a similar abstraction, but, with less pessimistic views about men, they imagined a peaceful "state of nature" and argued for more democratic forms of Government.

Social Contractualism, as an abstract theory, is in the origin of modern political thought. In contrast to Suárez's traditional political theories, modern thinking does not conceive a natural distribution of powers (economic and political) between families and Government, and so do not trace a limitation in the latter's competencies.

This "freedom of contract" about the community and its institutions of Government apply to its formation, like in Suárez, but extends to its rules, unlike in the Jesuit's view. Economic power (in the old sense of house management) could so be delegated to the Government. Suárez conceived the political body of the community as a thing. The new vision subjectivizes the political body and its head, the Government, as can be seen in popular expressions in different languages like "Nanny State" in English or "Vater Staat"

\footnotetext{
22 Strauss (1987).

23 During the English Civil War (1642-1651). Published in 1651.

24 Hobbes (1965), p. 97.
} 
in German. Even subjective values like Solidarity have fallen into the competencies of the Government nowadays.

The break in political philosophy, started by Hobbes and other authors, replaced traditional concepts about the origin of the community by the abstraction of a "state of nature", whose characteristics will depend on the author's vision of the forms of governments and the meaning and use of the authority. This process leads to "contractualism", a necessary tool to deduce the passage of that theoretical natural state, in which there is not yet a public authority, to constituted societies and governments. For Dalmacio Negro Pavón, contractualism leads to replace two natural conceptions, people and government, by two artifices, coming from an imagined state of the things on which abstraction works to give rise to political theory, which are society and the state ${ }^{25}$.

Contrary to contractualists like Hobbes or Rousseau, Suárez does not start from an abstract "state of nature" in which there is a conglomeration of men who, in terms of Negro Pavón, only "coexist" but do not "live together"26.

IV

\section{IMPORTANCE OF THE THEOLOGICAL CONCEPT OF “ORIGINAL SIN"}

The abstract state of nature used by social contractualists to explain community is related to the relegation of the Christian concept of "original sin". This theological assumption was in the base of

25 "Contractualism rests on the imaginary pre-existence of a state of nature. In such a state, an extreme political situation, there is not a people but only a group of scattered individuals who, submerged into a permanent fear of losing everything they own, first life, barely coexist. To make life in society possible, Hobbes invented his two great devices. The Society as the place where the group of individuals seeks the satisfaction of their egoism. The State to guarantee social life - justice - with its power of coercion. It is as if in the Society people coexisted and in the State lived together." (translated from Negro Pavón, 2008, p.14).

26 "The explanation of the existence of societies by an act of will falls into the utilitarian interpretation, which, absolutized like that of Hobbes and contractualists in general, is completely wrong and brings living together back to mere coexistence" (translated from Negro Pavón, 2008, p.19). 
Suárez theories about the origin and nature of community and could be considered, to some point, his "state of nature". This view, rather than define men as benevolent or evil, emphasizes the limitations of human beings in a fallen world. Social contractualists views about the "state of nature", specifically those that are positive like Locke and especially Rousseau's ones, tend to somehow negate the idea of original sin. As these theories tend to conceive man as good by nature but worsened by social and political circumstances, they use to suggest common or governmental action to restore the original state of nature, with no reference to the limitations in human nature that traditional philosophers explained with the concept of original sin.

Ernst Troeltsch ${ }^{27}$ wrote about the psychological and social consequences of neglecting this theological concept. In Troeltsch's views, Catholicism identifies the fall from Grace and men's leaving of the Biblical Paradise with the need of institutions like private property and the State. Both private property and State would be necessary consequences of original sin, and the Church would defend them on this ground despite their inherent imperfection ${ }^{28}$. The Protestant Reformation saw the seeds for the change of this view, as Luther conceived human nature as "irredeemably corrupt" and justified governmental use of force to keep peace ${ }^{29}$. This way, in Troeltsch's views, Luther Christianity would have lost its civilizing impulse and "left secular rulers free to behave unscrupulously without fear of religiously inspired protest" 30 .

Max Weber declared his admiration for the work of his colleague and friend Ernst Troeltsch, and the latter's influence on Weber's sociology of religion is remarkable. Weber famously wrote about the influence of religious concepts on modern economic mentality in his seminal work The Protestant Ethics and the Spirit of Capitalism ${ }^{31}$. In

27 Ernst Troeltsch (1875-1923), German Protestant theologian.

28 Liebersohn (1988), p. 136.

29 Rothbard found also practical reasons under this justification: "Luther had to rely for the spread of his religion on the German and other European monarchs; his preaching of all-out obedience to the ruler was reinforced by this practical concern" (Rothbard, 2006, p. 138).

30 Ibid.

${ }^{31}$ Die protestantische Ethik und der Geist des Kapitalismus. 
accordance with Harry Liebersohn, Weber's The Protestant Ethics focused on individual anxiety as the motive for social behavior while Troeltsch's The Social Teaching "focuses on social groups and the logic of their collective impulse toward new heaven and earth"32.

Weber mentioned Milton's poem Paradise Lost as an example of human confidence in redeeming the world with their work, and idea that developed from Calvinism. Both Weber and Troeltsch pointed out to the Protestant worldview, later transformed into secularized forms, as the origin of a peculiar mentality that conceives the state and the government as tools to redeem society and took back mankind to its happy and "heavenly" original state of nature.

This idea was further developed by Eric Voegelin ${ }^{33}$. Voegelin went further into the effects of ideas about the state of human nature. In his opinion, ideologies ("political religions" in his words) immanentize the Christian Eschaton, trying to bring a heaven-like state to the real world. Nazism, socialism, communism and other ideologies work this way, not only in the negation of the original sin but in getting over the fallen world by constructing a perfect one, usually with hard work and fight. The political body of the community, in the vision of the ideologies, should lead all this efforts and sacrifices for the construction of a perfect world.

Voegelin also thought that this mentality has its roots in Hobbes contractualism, but added that the contractual symbolism which the English author used is not the essence of the matter. The main effects would come, according to Voegelin, from the psychological side, as people would conceive the political head of the community as a new corpus mysticum ${ }^{34}$. Hobbes contractualism would be a negation rather than an affirmation of the principle of representation, that is elementary in Suárez's political philosophy. In the contracting act, the covenanters would cease to be self-governing persons and would merge their power drives into a new person, the commonwealth. The carrier of the new person, the

32 Liebersohn (1988), p. 122.

33 Eric Voegelin (1901-1985), German-American political philosopher.

34 "The combining into a commonwealth under a sovereign may express itself in legal form, but essentially it is a psychological transformation of the combining persons" (Voegelin, 1987, p. 182). 
sovereign, would not have, like in Suárez thinking, a limitation of powers natural to the political head of the commonwealth as a thing. As the commonwealth is no longer conceived as a thing, but rather as a person entitled with powers that covenanters had before and have agreed to lose by contract, it could hold all the powers that previously belonged to families. In Voegelin words, "the single human persons cease to exist and merge into the one person represented by the sovereign" 35 .

Considering Hobbes "state of nature", covenanters would not give up their power toward a summum bonum, but rather motivated by fear of the summum malum. Under a skeptical mentality, unlike under a traditional one, death of the body and not condemnation of the soul would be the greatest of fears. Under such premises, "Gnostic thinkers, leaders and their followers interpret a concrete society and its order as an eschaton" 36 and so apply their construction to concrete social problems.

Like Voegelin, Belloc wrote about a modern tendency of "deification of the State" 37 , which far roots also placed in the gnostic heresy. The absence of differentiation between the political and "oeconomic" spheres, which were traditionally attributed to public power and families respectively, would be a consequence of the alleged omnipotence of the State and a short of unlimited faith in its possibilities of leading society to a better future. Belloc was in favor of an extension of the suffrage based on the expansion of the number of owners, not on its mere extension to the non-owners, because he feared the consequences of the latter voting under economic and not political criteria ${ }^{38}$.

35 Voegelin (1987), p. 183.

36 Ibid, p. 166.

37 "But the sense of an absolute civil government at the moment of the Reformation was something very different. It was a demand, an appetite, proceeding from the whole community, a worship of civil authority. It was deification of the State and of law; it was the adoration of the Executive. 'This governs me; therefore I will worship it and do all it tells me.' Such is the formula for the strange passion which has now and then seized great bodies of human beings intoxicated by splendor and by the vivifying effects of command." (Belloc, 1930, p. 218).

38 Belloc (1897), p. 23. 


\section{$\mathrm{V}$ \\ CONCLUDING REMARKS}

Hayek and Belloc wrote about a change of direction, an abandonment of the right road, in the last part of the XIX Century. The change affected especially the role of the state in organizing both the private and the public life of citizens. In Suarezian terms, this could be expressed as the "usurpation" of the economic (in the restricted sense of "management of the house") power of the families by the Government, to which only the political power corresponds. This "usurpation" could also be considered a "delegation" in the terms of modern political philosophy.

Modern political philosophy is based on social contractualism, a theory that, starting from an abstract state of nature, conceived community as a pact. From this point of view, pacts would configure not only the community and his political body, like in Suárez's political philosophy, but also the rules, unlike in the Jesuit view. From this point of view, there would be no natural limitation on Government competencies, as they would be determined by pacts between its members. Government could this way interfere not only in economics but in any other issue that was traditionally conceived as an exclusive attribution of the families.

Traditional philosophical concepts may be important to understand the changes of mentality regarding the nature of community and the role of the political head, and their economic effects and consequences. These traditional concepts could be already found in Aristotle and were developed to democratic and representative forms by late Spanish Scholastics, like Francisco Suárez. The reformulation of these concepts, and of the target of political philosophy, by later authors, in particular after Hobbes, led to changes in mentality that paved the way for future political and economic developments. Theological concepts, like original sin, have a role in this process, as its negation implies a philosophy that denies human limitations in the construction of a perfect world. Ideologies would try to use the powers of the State as the tool to overcome this imperfect state of things. The simplification of the traditional doctrine combined with the negative vision of human nature tended to justify the extension of the power and authority of the state. Some countries, 
like Bismarck's Germany, started to expand the functions and power of the government, precisely at the time and place where Hayek and Belloc located the abandonment of the right road.

Being the economic power delegated by families into a personified political body, the State, and the possibilities of improvement almost infinite, public policies would expand to almost every aspect of the life of the people. The message from Hayek, Belloc, Voegelin and many others would be that unchecked expansion of the State over what could be considered, according to traditional political philosophy, its natural competencies, could eventually lead to totalitarianism.

\section{REFERENCES}

Belloc, H. (1897): “The Liberal Tradition”, Essays in liberalism by six Oxford men, London. Cassell \& Company.

- (1930): Europe and the Faith, New York, The Paulist Press.

- (1954): How the Reformation Happened, London, Jonathan Cape.

- (2007): The Servile State, New York, Cosimo Classics.

Blaug, M. (1983): The Methodology of Economics or how Economists Explain, New York, Cambridge University Press.

Cendejas Bueno, J. L. (2017): "Economics, chrematistics, oikos and polis in Aristotle and St. Thomas Aquinas", The Journal of Philosophical Economics: Reflections on Economic and Social Issues, X n. 2, pp. 5-46.

Gómez Rivas, L. (2014): Historia del Pensamiento Económico, Ávila, Servicio de Publicaciones de la Universidad Católica de Ávila.

Grice-Hutchinson, M. (1952): The School of Salamanca. Readings in Spanish Monetary Theory, 1544-1605, Oxford, Clarendon Press.

Hayek, F.A. (1958): Individualism and Economic Order, Chicago, The University of Chicago Press.

- (1992): The fatal conceit: the errors of socialism, London, Routledge.

- (2006): The Road to Serfdom, New York, Routledge Classics.

- (2013): Law, Legislation and Liberty, London, Routledge.

Hobbes, TH. (1965): Leviathan, Oxford, Oxford University Press.

Huerta de Soto, J. (2017): “Anarquía, Dios y el Papa Francisco", Procesos de Mercado: Revista europea de economía política, XIV n. 2, pp. 205-218. 
Liebersohn, H. (1988): “The Utopian Forms of Religious Life. Ernst Troeltsch's 'The Social Teachings of the Christian Church'", Archives de Sciences Sociales des Religions, n65/1, pp. 121-143.

López Atanes, F.J.; Bustos, I.; \& Villena, P.M. (2010): Suárez, una aproximación al tratado de las leyes y la defensa de la fe, Madrid, Unión Editorial.

Mccarthy, J. (1978): Hilaire Belloc: Edwardian Radical, Indianapolis, Liberty Press.

Medema, S.G. \& Warren, J.S. eds. (2013): The History of Economic Thought: A Reader, $2^{\text {nd }}$ edition, New York, Routledge.

Negro Pavón, D. (2008): La situación de las sociedades europeas, Madrid, Unión Editorial.

Pontifical Council for Justice and Peace (2005): Compendium of the Social Doctrine of the Church, City of the Vatican, Editrice Vaticana Library.

Prieto López, L. (2018): Francisco Suárez, Tratado de la obra de los seis días (forthcoming).

Rothbard, M.N. (2006): Economic Thought before Adam Smith, Auburn, Ludwig Von Mises Institute.

Strauss, L. (1987): Niccolo Machiavelli. STRAUSS, L. \& CROPSEY, J. eds.: History of Political Philosophy, Chicago, The University of Chicago Press.

Troeltsch, E. (1992): The Social Teaching of the Christian Churches, vols. $1 \mathcal{E}$ 2, Louisville (KY), Westminster John Knox Press.

Voegelin, E. (1987): The New Science of Politics: An Introduction, Chicago, The University of Chicago Press.

Weber, M. (1992): The Protestant Ethic and the Spirit of Capitalism, London, Routledge. 